Journal of Science and Technology, Vol. 29, No. 3 (2009), pp 102-113 102

(C) 2009 Kwame Nkrumah University of Science and Technology (KNUST)

\title{
THE STRUCTURE OF LABOUR MARKET AND DEMAND FOR HIRED LABOUR FOR OIL PALM PRODUCTION IN THE WESTERN REGION OF GHANA
}

\author{
A. Mensah-Bonsu, D.P.K. Amegashie, and S. Gyasie \\ Department of Agricultural Economics and Agribusiness \\ University of Ghana \\ Legon
}

\begin{abstract}
The study uses cross sectional data from randomly selected oil palm famers to describe the structure of the labour market and estimate the factors which influence oil palm farmers' demand for hired labour in the Western Region. Descriptive statistics and the ordinary least square regression techniques have been applied in the analysis. The results suggest that the structure of labour for oil palm production typifies a small-scale agricultural production, with some farmers using contract labour (14 percent), salaried labour (11 percent) and fertilizer (30 percent) in production. The estimated regression results show that the value of investment in other inputs (e.g. fertilizer), village wage rate, size of oil palm farm and higher educational attainment have significant and positive influences on oil palm farmers' demand for hired labour. The distance of the farm from home has a negative and significant influence. The estimated hired labour demand elasticities for farm size, value of other inputs, village wage rate and distance are inelastic. It is noted that issues on labour requirement of farmers should be based on economic considerations such as the structure of labour of the farmers, farm size, village wage rate and cost of other productive inputs. For oil palm production, carrying of fresh fruit bunches and slashing are two main activities that could be mechanized, but may lead to retrenchment of female and male hired labour, respectively.
\end{abstract}

Keywords: structure of labour, hired labour, oil palm production, demand elasticities

\section{INTRODUCTION}

Literature reveal how the structure of labour used in production can be described. Hill and Ray (1987) described the structure of United States' agricultural labour with regards to parameters such as the size of the labour force, type of labour used (family or hired labour), age and sex of labour or employment status (i.e. which labour does what). A FAO economic and social development paper described the struc- ture of labour force in terms of age and sex distribution, dependency ratio, available workdays, required workdays and level of employment (FAO, 1986).

Labor as a factor of agricultural production is generally of overwhelming importance (Cleave, 1974) and makes up about $90 \%$ of the costs of production (Dvorak, 1996) in many African farming systems. Labour is the most critical 
and most limiting resource in agricultural production when all the production factors including land, capital, technology, and labour are considered in Africa (Flinn and Zuckerman, 1979; Olayide and Atobatele, 1980). Agricultural labor consists of family and hired labor. Family labour is becoming less plentiful, hence smallholder farmers will have to rely on hired labour, owing to the decline in polygamy, increasing rural-urban migration and increasing school attendance of children (Johnson, 1982; Ghana Statistical Service, 1995). Hired labor is particularly of interest because estimates by the FAO indicate that $50 \%$ of the expected crop yield increases, necessary to stop the decline in per capita food output in sub-Saharan Africa will depend on increased use of purchased inputs (Vlek, 1990). Empirical evidence suggests that off-farm employment may affect the organisation of the farm, e.g. the division of farm labour between men and women, the use of hired workers, or the use of less labourintensive practices (Benjamin and Kimhi, 2006).

The government policy under the Ghana Poverty Reduction Strategy (GPRS) favours crops such as oil palm, cotton, rubber and cocoa, and targets creating gainful employment for poverty reduction through labour intensive as opposed to capital intensive technologies, but using simple mechanization to reduce the drudgery of the farmers for farm operations that require heavy labour input (Ghana Poverty Reduction Strategy, 2003). This policy emphasizes the fact that human labour remains very important in modernized agriculture; hence it is useful to conduct research on the types of labour engaged in agriculture and their earnings. There is also insufficient empirical evidence to explain the reason why in the same locality some farmers use hired labour whereas others do not. The present study, therefore, addresses the following research questions: (i) what is the structure of labour employed in oil palm production? (ii) what are the determinants and their effects on the demand for hired labour by oil palm farmers? The specific objectives of the study are: to describe the structure of labour employed in oil palm farm production in the Western Region of Ghana; to identify and estimate the effects of the determinants of demand for hired labour by oil palm farmers for maintaining the farms. The paper in studying the labour for oil palm production focuses on the labour used for oil palm maintenance activities like slashing, pruning and harvesting of fruits, but excludes labour required for establishing the farms. The Western Region was selected for the study because it is one of the major oil palm producing areas in Ghana: Located in the region are two of the major oil palm plantations in Ghana namely Benso and National Oil Palm Plantations, in addition to other small and medium scale plantations. The results from this study will afford policy makers the opportunity to formulate policies to promote the factors which positively influence the farmers demand for hired labour and develop coping strategies for the factors which hinder their ability to hire labour.

\section{METHODOLOGY}

Description of the Structure of labour for oil palm production (maintenance)

The present paper follows two approaches used by Hill and Ray (1987) to describe the structure of labour of a production unit. The first approach analyzes the composition of labour while the second estimates the proportion of labour cost in total production cost. First, the composition of labour in terms of type of labour employed, gender, and employment status in oil palm production are described using frequency, percentages and other summary statistics. In the second approach the shares of labour and other factor inputs in the total cost for maintaining matured oil palm farm are estimated and expressed in percentages.

\section{Measuring the hired labour demand function}

The farm household structural hired labour demand function is estimated from variations in local wage, farm size and other farm household characteristics such as adult household size. To determine the oil palm farmers' demand for hired labour, the following maintained assumptions are made (i) rational oil palm farmers maximize their output subject to cost con- 
straints and (ii) there is diminishing marginal rate of return to input used. The oil palm farmers' demand for hired labour is based on the theory of the firm, where the farmer seeks to maximize output subject to a cost outlay. Assume a rational farmer utilizes two variable inputs $\mathrm{X}_{1}$ and $\mathrm{X}_{2}$ representing labour and land (or any other variable input), respectively, to produce a single maximum output (Q). The farmer's constrained output maximization problem is presented as:

Maximize output:

$$
\begin{aligned}
& \mathrm{Q}=f\left(X_{1}, X_{2}\right) \\
& \bar{C}=W X_{1}+R X_{2}
\end{aligned}
$$

where, $\overline{\boldsymbol{C}}$ denotes cost, $W$ and $\mathrm{R}$ represent

unit prices of labour and land (other input), respectively. A Lagrangean form of the problem of the farmer is given as:

$$
\begin{aligned}
& V=Q+\lambda\left(\bar{C}-W X_{1}-R X_{2}\right) \\
& \frac{\partial V}{\partial X_{1}}=\frac{\partial Q}{\partial X_{1}}-\lambda W=0 \\
& \frac{\partial V}{\partial X_{2}}=\frac{\partial Q}{\partial X_{2}}-\lambda R=0 \\
& \frac{\partial V}{\partial \lambda}=\bar{C}-W X_{1}-R X_{2}=0
\end{aligned}
$$

Given that assumptions (i) and (ii) are met, rearranging the first order conditions and solving equations (4), (5) and (6) simultaneously gives the demand functions for labour and land (other variable input) as functions of $\mathrm{W}, \mathrm{R}$, and $\mathrm{Q}$ respectively as:

$$
\begin{aligned}
& X_{1}=\left(W, R, Q^{\prime}\right) \\
& X_{2}=\left(R, W, Q^{\prime}\right.
\end{aligned}
$$

A structural form of the demand function for hired labour may be expressed from equations (7) and (8) as a function of the relative price of farm inputs, farm output level and other relevant socio-economic variables. The theoretical literature suggest that higher (lower) prices of labour (W) and other input (R) would, respectively, decrease (increase) and increase (decrease) the demand for hired labour while higher (lower) desired output (Q) would increase (decrease) the demand for hired labour. In the present study, factors that influence farm output (income) level such as land size, household size and other input quantity (or value) replace the direct effect of farm output in the structural model for hired labour. Other factors which affect farm output include socioeconomic factors like education and income in general. Also, for a tree crop the age of the trees would affect the output. There are empirical evidences to suggest that availability of labour also determine the size of cultivated fields, implying simultaneity between cultivated land size and labour demand. Since the present study focuses on the demand for (hired) labour for the maintenance of established oil palm farms (with mean age of about 9.6 years, Table 1), it is assumed that the sizes of the established oil palm farms are given and therefore not determined by the availability labour. A single equation technique is therefore followed to estimate the demand for hired labour. An instrumental model attempted does not give better estimation results.

Using the ordinary least square estimation technique the double log, linear and semi-log models of the structural form are estimated. On the basis of the estimated adjusted $\mathrm{R}^{2}$, F-statistics, signs of the parameters and significance of the student t-statistics, the double log model gives the best results and is therefore selected, over the other models, for the discussion. The estimated double log model of demand for hired labour by oil palm farmers is given as:

$$
\begin{aligned}
& \ln L=b_{0}+b_{1} \ln H+b_{2} \ln A+b_{3} \ln K+ \\
& b_{4} \ln W+b_{5} \ln D+b_{6} \ln S+b_{7} \ln I+b_{8} E_{1}+b_{9} E_{2}
\end{aligned}
$$

where, $L$ is the units of labour (man-days) hired for oil palm production (maintenance), $H$ is the size (hectares) of oil palm farm of the farmer, $A$ is the average age (years) of oil palm trees on the farm, $K$ is the total value (in cedis) of other 
inputs used, $W$ is the average farm wage (in cedis) paid by the farmer, $D$ is the distance (in kilometers) of oil palm farm from home, $S$ is the number of adults of the farmer's household, $I$ is the amount of income from non-oil palm sources, $E_{1}$ and $E_{2}$ are dummies for average education of primary/JSS/middle school and SSS or higher for the members of a household. The expenditure for contract labour has been divided by the number of days taken to accomplish it, while expenditure per month for a salaried labour has been divided by 22 days to obtain the daily values. The other is daily wage paid for daily rated labour. The average farm wage used is the average of the three daily values paid by a farmer. The $b_{1}, b_{2}, b_{3}, b_{4}, b_{5}, b_{6}$ $b_{7}, b_{8}$ and $b_{9}$ in equation (9) are the coefficients of the explanatory variables which are estimated using ordinary least squares regression technique. In order to account for clustering of the farm wage assigned farmers with zero hired labour around the average for a village, robust standard errors have been estimated. Since in equation (9) the relationship between the demand for hired labour and each of the continuous variables on the right hand side, namely farm size $(H)$, average age of oil palm trees $(A)$, total value of other inputs $(K)$, average farm wage $(W)$, distance $(D)$, adult size $(S)$ and nonoil palm income $(I)$ is represented by a log-log (double $\log$ ) relationship, their estimated coefficients give their respective elasticities of demand for hired labour directly. For example, the elasticity of demand for hired labour due to farm size $\left(e_{L H}\right)$, defined as proportionate change in demand for hired labor due to a proportionate change in farm size, is given directly by the estimated coefficient $b_{1}$ from equation (9) as

$$
e_{L H}=(\partial L / \partial H)(\bar{H} / \bar{L})=\partial \ln L / \partial \ln H=b_{1}
$$

On the other hand, because the relationship between the demand for hired labour and each of the discrete (dummy) variable is a log-linear type, the elasticity of demand for hired labour due to each of the discrete (dummy) variable (i.e. $E_{1}$ and $E_{2}$ ) is given by the product of the estimated coefficient (from equation 9) and the mean (from Table 1) of the discrete variable.
For instance, the coefficient for $E_{l}$ is obtained as

$$
b_{8}=\partial \ln L / \partial E_{1}=\partial L / \partial E_{1} * \bar{L}
$$

and therefore the elasticity of demand for hired labour due to $E_{1}, e_{L E l}$, is given by

$$
e_{L E_{1}}=\left(\partial L / \partial E_{1}\right)\left(\bar{E}_{1} / \bar{L}\right)=\left(\partial \ln L / \partial E_{1}\right) \bar{E}_{1}=b_{8} \bar{E}_{1}
$$

The size of oil palm farm is obviously expected, a priori, to exert a positive effect on hired labour demand. Larger oil palm farm size requires greater amount of labour input (whether family or hired) and therefore the need for hired labour to supplement the available family labour. The effect of the average age of oil palm trees on hired labour demand is uncertain. Investment made in other inputs such as fertilizer is expected to exert a positive effect on the farmers' demand for hired labour since the application of such inputs would require additional labour. High wage rate reduces the purchasing power of the farmer and therefore the farmers' demand for hired labour. The farm wage paid by a farmer is therefore expected to have a negative effect on the demand for hired labour.

The distance of the farm from home serves as a proxy for the location of the farm. It also expresses the accessibility of the farm. The distance to farm is expected to have a negative effect on the demand for hired labour. This is because farms which are far from home and not easily accessible may find it difficult to attract the needed hired labour. The size of the family labour is expected to have a negative effect on the demand for hired labour. If more adult family labour is available for farm work, then the tendency to hire additional labour is low, unless the family labour available is less than what is required. Both farm and non-farm income is expected to exert a positive effect on the demand for hired labour. The average SSS or higher level of education of a household is expected to exert a positive effect on the farmer's demand for hired labour as more educated people would seek off-farm employment rather than offer farm labour. Conversely, the average 
household education level of middle school/JSS or lower is expected to exert a negative effect on the farmer's demand for hired labour. Enete et al (2005) estimated a Tobit model for hired labour and found out that the characteristics of the household head (age and number of years of formal education), the size of the household farm, good market access, and population pressure motivate households to apply hired labour in cassava production. Also, Benjamin and Kimhi (2006) from an estimated multinomial model reported that hired farm labour increases with the farmer's qualifications, perhaps substituting for the couple's labour inputs while other adults in the household substitute for the farm labour input of the farm couple and hired workers.

\section{Data Source}

The survey was conducted in February 2005. Eighty-one (81) oil palm farmers were randomly drawn from nine communities in Ahanta West and Mpohor-Wassa East Districts. The two districts were purposively selected to include the major oil palm producing communities in the region. The communities namely Agona-Ahanta, Aketenkye, Ewusiedjoe, Tumentu, and Abura were randomly selected from Ahanta West District. The communities selected from the Mpohor-Wassa East District were Ayiem, Adum-Dominase, Adum-Banso and Wassa-Mpohor. Nine farmers were interviewed individually in each community. The data was collected using structured questionnaire. The data included the explanatory variables in equation (9), types of labour used and their quantities and other socio-economic variables. The summary statistics of the regression variables are presented in Table 1. Table 1 shows considerably variations in the regression variables, including farm wage per hired labour in a given village. Kevane (1994) found out that village labour wages vary considerably, and are not uniform across workers, villages or agricultural season.

Table 1: Summary Statistics of Regression Variables

\begin{tabular}{lrrrrr}
\hline \multicolumn{1}{c}{ Variable } & \multicolumn{1}{c}{ Obs } & \multicolumn{1}{c}{ Mean } & \multicolumn{1}{c}{ Std. Dev. } & \multicolumn{1}{c}{ Min } & Max \\
\hline Hired labour Qty (mandays) & 81 & 216.07 & 471.86 & 0 & 3901 \\
Farm size (ha) & 81 & 5.61 & 11.83 & 0.8 & 106 \\
Tree age (years) & 81 & 9.64 & 5.28 & 3 & 25 \\
Other variable cost (Cedis) & 81 & $3,430,269$ & $1.18 \mathrm{e}+07$ & 50,000 & $1.06 \mathrm{e}+08$ \\
Ave. Farm wage (Cedis/manday) & 81 & $20,792.65$ & $7,905.40$ & 8600 & 40,000 \\
Distance: home - farm (Km) & 81 & 2.33 & 2.27 & 0.20 & 18 \\
Adult size (count) & 81 & 4.04 & 2.19 & 1 & 11 \\
Non oil palm income (Cedis) & 81 & $437,160.50$ & $572,213.30$ & 0 & $2,500,000$ \\
Education (level) & & 0.185 & & & \\
$\quad$ No education & 81 & 0.617 & 0.391 & 0 & 1 \\
$\quad$ Ave. education of JSS & 81 & 0.198 & 0.489 & 0 & 1 \\
$\quad$ Ave. education of SSS & 81 & & 0.401 & 0 & 1 \\
Variation in Farm wage (Cedis/manday) & & & & & \\
Ahanta & 9 & $19,808.64$ & $10,000.92$ & 8,600 & 36,000 \\
Aketenkye & 9 & $18,988.24$ & $6,426.65$ & 12,000 & 30,000 \\
Ewusiedjoe & 9 & $12,705.19$ & $5,018.82$ & 8,800 & 24,000 \\
Tumentu & 9 & $19,734.01$ & $6,952.62$ & 13,000 & 35,000 \\
Abura & 9 & $22,472.84$ & $10,325.12$ & 10,000 & 40,000 \\
Ayiem & 9 & $25,066.72$ & $3,949.41$ & 20,000 & 33,000 \\
Adum-Dominase & 9 & $25,687.44$ & $4,288.01$ & 22,000 & 35,000 \\
Adum-Banso & 9 & $21,177.30$ & $8,650.11$ & 11,000 & 37,000 \\
Wassa-Mpohor & 9 & $21,493.45$ & $7,980.71$ & 13,000 & 36,000 \\
\hline
\end{tabular}

Source: Survey Data, 2005 
RESULTS AND DISCUSSION Structure of labour employed for oil palm production

Composition of labour

Different types of labour namely, hired labour (consisting of daily rated labour, salaried labour, and contract labour), family labour, exchange labour and communal labour are used by the sampled oil palm farmers (Table 2).

More farmers ( 47 percent) employed hired labour only for maintaining their oil palm farms and 30 percent employed family labour only. About 18 percent of the farmers used both family labour and daily rated (i.e. hired) labour. The results imply that hired labour is an important source of labour for oil palm farmers. This result may be inconsistent with the findings of Otoo (1993) and Ahiaphor (2003) in their studies of Central Region and Eastern Region, respectively, that the main source of labour employed on oil palm farms is family labour, but may corroborate the findings of Okyere (1985) that there has been a shift from the use of family labour to hired labour in oil palm and coconut production. Meanwhile, the mean labour supplied per hectare by family labour (65.64 man-days/ha) is significantly (at 1 percent level) higher than the amount supplied by hired labour (41.13 man-days/ha) for farm maintenance. Thus, it is important to note that even though more farmers use hired labour (Table 1 ), in terms of magnitude of labour supplied per hectare (i.e. labour use intensity), the amount supplied by family labour is significantly higher than the amount supplied by hired labour. The coefficients of variation for the average labour supplied per hectare by family labour and hired labour are quite high (0.94 and 0.62 respectively), suggesting that the labour supplied per hectare (either family or hired labour) for the maintenance of oil palm farms is not stable.

The relationship between the type of labour used by the farmers and the size of oil palm farm indicates that farmers using hired labour only for the maintenance of their oil palms have larger average farm size; about 8.34 hectares (which include 4.8 hectares, 5.15 hectares and 16.95 hectares for farmers who employed contract labour only, daily rated labour only and salaried workers only, respectively). Farmers using family labour only have a relatively smaller average farm size, about 2.90 hectares, while those who employed family and daily rated labour have average farm size of about 3.33 hectares. Also, farmers who engage in exchange or communal labour have average farm size of about 3.00 hectares. The implication is that if farmland is available, then the use of hired labour would be important for putting larger size of land under oil palm cultivation.

The maintenance of matured oil palm farms involves a number of activities namely harvesting, slashing, pruning, ring-weeding and fertil-

Table 2: Distribution of Farmers by the Type of Labour Employed

\begin{tabular}{lcc}
\hline Type of labour & Frequency & Percentage \\
\hline Family labour & $\mathbf{3 9}$ & $\mathbf{4 8}$ \\
Family labour only & 24 & 30 \\
Family \& daily rated labour (hired labour) & 15 & 18 \\
Hired labour only & $\mathbf{3 8}$ & $\mathbf{4 7}$ \\
Daily rated labour only & 13 & 16 \\
Salaried labour only & 11 & 14 \\
Contract labour only & 14 & 17 \\
Communal or exchange labour & $\mathbf{4}$ & $\mathbf{5}$ \\
Total & 81 & 100 \\
\hline
\end{tabular}

Source: Survey Data, 2005 
izer application (Table 3). More farmers (41 percent) employed family labour only for harvesting, while 28 percent of the farmers used hired labour only for harvesting. The results may be attributed to the fact that harvesting requires skilled labour which is often scarce for most oil palm farmers, particularly during the peak season, and the need to harvest the fruits on time once they are matured, hence more farmers use family labour for harvesting. Some farmers also conceded using family labour for harvesting, because of financial constraint. On the other hand, more farmers (35 percent) used hired labour only compare to 31 percent who used family labour only for carrying of fresh fruit bunch (FFB) at harvesting. Also, about 30 percent of the farmers employed both family labour and hired labour (i.e. daily rated labour) for carrying of fresh fruit bunches at harvesting. Slashing under the oil palm trees is mostly undertaken with hired labour (58 percent), while ring-weeding is mostly undertaken with family labour only (47 percent). Slashing is considered strenuous, requires less skills, hence farmers, perhaps, preferred to use hired labour to under- take this activity. But ring-weeding is considered less strenuous and non-hazardous, hence the use of family labour. Table 3 also shows that 43 percent of the oil palm farmers used family labour only to undertake pruning, while 41 percent of them engaged hired labour only.

It is evident from the results that family labour is used mainly for harvesting, pruning and ringweeding, whereas hired labour is used mostly for slashing and carrying of FFB (Table 3). Farmers may want to use family labour for the activities requiring the use of skilled labour and hired labour for activities that require less skill labour and supervision. For the activities performed with hired labour, the results suggest that, contract labour is used for farm activities which required little or no supervision such as slashing and pruning (32 percent and 20 percent respectively).

The labour hired for oil palm production may also be gender specific. The results reveal that all the farmers who employed hired labour for harvesting used only male labour. The carrying of harvested FFB is mainly a female activity

Table 3: Structure of Labour Used by Oil Palm Farmers

\begin{tabular}{|c|c|c|c|c|c|c|}
\hline \multirow[b]{2}{*}{ Type of Labour } & \multicolumn{6}{|c|}{ Percentage of farmers undertaking an activity by type of labour used } \\
\hline & Harvesting & $\begin{array}{l}\text { Carrying } \\
\text { FFB }\end{array}$ & Slashing & Pruning & $\begin{array}{l}\text { Ring } \\
\text { weed- } \\
\text { ing }\end{array}$ & $\begin{array}{c}\text { Fertilizer } \\
\text { applica- } \\
\text { tion }\end{array}$ \\
\hline family labour only & 41 & 31 & 26 & 43 & 47 & $\mathbf{2 0}$ \\
\hline family/exchange labour & 2 & -- & 1 & 1 & -- & -- \\
\hline family/daily rated labour & 25 & 30 & 13 & 5 & 3 & -- \\
\hline family/salaried labour & -- & 1 & 1 & -- & -- & -- \\
\hline family/contract labour & -- & -- & 1 & 2 & 1 & -- \\
\hline Hired labour only & 28 & 35 & 58 & 41 & 27 & 10 \\
\hline daily rated labour only & 15 & 25 & 15 & 10 & 9 & 6 \\
\hline salaried labour only & 11 & 6 & 12 & 10 & 11 & 1 \\
\hline contract labour only & 2 & 3 & 29 & 17 & 7 & 3 \\
\hline daily rated/salaried labour & -- & -- & -- & 3 & -- & -- \\
\hline daily rated/contract labour & -- & 1 & 2 & 1 & -- & -- \\
\hline $\begin{array}{l}\text { Communal and Exchange } \\
\text { labour }\end{array}$ & 2 & 1 & - & 1 & - & - \\
\hline $\begin{array}{l}\text { Farmers not undertaking } \\
\text { activity }\end{array}$ & 2 & 2 & -- & 7 & 22 & 70 \\
\hline Total & 100 & 100 & 100 & 100 & 100 & 100 \\
\hline
\end{tabular}

Source: Survey Data, 2005

Journal of Science and Technology C KNUST December 2009 
(72.7 percent of hired labour). The results further show that, carrying of FFB was the only farm activity for which some farmers used the services of hired child labour (15.2 percent) ${ }^{1}$. Again, slashing, pruning and ring-weeding are male dominated activities, (male constitutes 94.9 percent, 97.5 percent and 75.9 percent of the hired labour input for these activities, respectively). The results imply that when hired labour is employed to undertake activities under oil palm production, harvesting, slashing, pruning and ring-weeding are mainly performed by male hired labour, while carrying of FFB is performed by female hired labour.

The remunerations received by hired labour vary across gender and type of farm activity undertaken. Male hired labour received on average $\phi 19,217$ per day for carrying FFB, while female hired labour received on average about $\notin 16,056$, but the difference between the average wage received is not statistically significant. The results show that the proportion of the male wage received by the female for her labour effort in carrying harvested FFB is 0.84 , which is more than the male work equivalence of 0.70 per day allotted to female labour (Norman, 1973). This implies that female hired labour was paid a little more than her equivalent labour input for carrying FFB. This result may be attributed to the fact that, through experience or tradition, farmers consider carrying of FFB as female dominated task and that females are more efficient at carrying FFB, hence they are given a premium (about 14 percent points more of her work equivalence).

.Male and female hired labour received on average $\phi 23,864$ and $\phi 8,333$, respectively, per day for slashing under the oil palm trees and the difference between these average wages is, obviously, statistically significant at the one percent level. The proportion of the male wage received by female is about 0.35 , which is half of the male work equivalence of 0.70 per day normally allotted to female labour. The reason for the relatively lower wage paid to female employed for slashing is that, slashing is considered a strenuous job and therefore a female who takes up the job may be assigned a smaller task per day for them to perform better. For ring-weeding, males and female hired labour received about $\varnothing 17,304$ and $\varnothing 12,643$, respectively, per day and the difference between their average wages is significant at the 10 percent level. For ring-weeding the proportion of male wage paid to female is 0.73 , which is close to the male work equivalence of 0.70 per day normally allotted to female labour, suggesting that females employed for ring-weeding were paid about the equivalent of their labour effort.

\section{Farm maintenance cost}

Based on the labour cost analysis presented above and cost of physical inputs, the total cost of maintaining matured oil palm farms for the 2004 season is presented in Table 4 . The analysis ignored the cost of establishment of the farms because farmers could not remember the cost of establishment of their farms, particularly the old oil palm farms.

The results show that labour cost is the highest cost, representing about 87.1 percent of the total annual maintenance cost per hectare. Being the highest cost component in production, it is important for farmers to make efficient use of labour. The next highest cost, fertilizer input constitutes just 5.9 percent of average total annual maintenance cost of matured oil palm farms. The farmers cited high cost of fertilizer as the reason for the low investment in fertilizer. Only 30 percent of the farmers applied fertilizer (Table 3). As expected the share of labour in average cost for farmers using family labour ( 80.1 percent) is relatively lower than those for farmers using the daily rated labour

${ }^{1}$ Persons engaged to perform any of the farm activities on oil palm farm and are below 16 years were classified as Child labour. According to ILO Convention 138, Child labour is any economic activity performed by a person under the age of 15 years. Work which by its nature or circumstances in which it is carried out is likely to harm the health, safety or morals of children are considered as child labour. 
Table 4: Average Maintenance Cost per Hectare for Matured Oil Palm

\begin{tabular}{lcc}
\hline Input & Average cost (Cedis) & Percentage share \\
\hline Labour & $6,330,429$ & 87.1 \\
Fertilizer & 429,126 & 5.9 \\
Transportation & 261,962 & 3.6 \\
Herbicide & 59,219 & 0.8 \\
Raphia basket & 41,953 & 0.6 \\
Cutlass & 31,454 & 0.4 \\
Aluminum pan & 28,043 & 0.4 \\
Wellington boot & 25,612 & 0.4 \\
Sharpening stone & 23,219 & 0.3 \\
Hand gloves & 18,313 & 0.3 \\
Malayan knife & 7,425 & 0.1 \\
Harvesting chisel & 5,692 & 0.1 \\
Total & $7,262,450$ & 100 \\
\hline
\end{tabular}

Source: Survey Data, 2005

only (87.4 percent), contract labour only (88.1 percent) and salaried labour only (94.8 percent).

\section{Estimated hired labour demand equation for} maintenance of oil palm farms

The estimated double log model results for the demand for hired labour are presented in Table 5. The quality of the regression as determined by the coefficient of determination, $\mathrm{R}^{2}$, means that 54.5 percent of the variation in the farmers' demand for hired labour is explained by the explanatory variables included in the model. The estimated F-value is significant, indicating that the explanatory variables included in the regression exert a joint significant effect on the demand for hired labour by the oil palm farmers.

The regression results show that the value of other inputs used in production (e.g. fertilizer), village wage rate, size of oil palm farm, distance of the farm from home and average educational level of household of Senior Secondary School or higher are the factors which exert significant individual influence on the farmers' demand for hired labour. The estimated coefficients for farm size, value of other inputs, vil- lage wage rate and distance give their respective elasticity of demand for hired labour. The estimated elasticities suggest that the effects of farm size, value of other inputs, village wage rate and distance are inelastic, since the estimated value in each case is less than one.

The size of oil palm farm exerts a significant (at the 10 percent level) and positive effect on the demand for hired labour. The estimated elasticity suggests that a percent increase in farmland size under matured oil palm would increase hired labour demand by 0.639 percent. Otoo (1993) and Okyere (1985) have indicated a positive relationship between hired labour input and the farm sizes of oil palm farmers. Leones and Feldman (1998), similarly, have estimated positive effects of rice land size, coconut land size and upland crops land sizes on household demand for hired agricultural labour in Philippine. The value of other inputs used in production (e.g. fertilizer) exerts a positive and significant (at the one percent level) effect on the demand for hired labour. A percent increase in value of other inputs used in production would increase the demand for hired labour by 0.60 percent. The positive effect of the value of other inputs is expected because if a farmer 
Table 5: Estimated Results for Demand for Hired Labour (Double Log Model)

Dependent variable: $\ln$ (quantity of hired labour used)

\begin{tabular}{|c|c|c|c|}
\hline Explanatory variable & Coefficient & Robust Std. Error & t-value \\
\hline $\ln$ (Farm size) & 0.639 & 0.339 & $1.89^{*}$ \\
\hline $\ln ($ Age of tree $)$ & 0.480 & 0.333 & 1.44 \\
\hline $\ln$ (Value of other inputs) & 0.600 & 0.170 & $3.53 * * *$ \\
\hline $\ln ($ Ave. Farm wage rate) & 0.884 & 0.466 & $1.89 *$ \\
\hline $\ln$ (Distance of farm from home) & -0.462 & 0.210 & $-2.20 * *$ \\
\hline $\ln$ (Adult household size) & 0.390 & 0.311 & $1.25^{*}$ \\
\hline $\ln ($ Non-oil palm income) & 0.017 & 0.026 & 0.63 \\
\hline Aveg. education of JSS or lower ${ }^{1}$ & -0.314 & 0.444 & -0.71 \\
\hline Aveg. education of SSS or higher ${ }^{1}$ & 1.203 & 0.511 & $2.35^{* *}$ \\
\hline Constant & -15.304 & 5.283 & $-2.90 * * *$ \\
\hline $\mathrm{R}^{2}=0.5454$ & $71)=7.41$ & $\mathrm{MSE}=1.459$ & \\
\hline
\end{tabular}

Source: Estimated from Survey Data, 2005

${ }^{1}$ Comparison education level is no education

$*$ = significant at $10 \% \quad * *=$ significant at $5 \% \quad * * *=$ significant at $1 \%$

makes investment in inputs such as fertilizer, then the investment would require an additional labour input probably from hired labour to ensure that (i) the investment does not go waste and (ii) there would be enough labour to harvest the expected increase in output from the investment. The implication is that programmes that encourage the use of productive inputs like fertilizer should recognize the potential labour that would be required.

The distance of the farm from home exerts a negative and significant effect on demand for hired labour. The estimated elasticity suggests that a percent increase in the distance between the farm and home would lead to a 0.46 percent decrease in demand for hired labour for oil palm production activities. This result implies that the further away the farm is from home, the less the farmer's demand for hired labour to work on the farm. The implication is that accessibility of the farm is very important for encouraging farmers to use more hired labour for their farm activities.

The results also show that the average educational level of SSS or higher attained by a household exerts a positive and significant (at 5 percent level) effect on the demand for hired labour. The calculated elasticity of demand for hired labour due to SSS or higher level of education is $0.24(0.198$, from Table 1 , multiplied by 1.203 , from Table 5). Higher educational level (continuous schooling) in the household delays the timing of the release of family labour for the farm work, hence the engagement of external (hired) labour, for optimum production. Rourke (1974) also observed that education among other changing factors within the Ghanaian economy is likely to influence the demand and supply of agricultural labour in the near future. The average educational level of JSS or lower attained in the household exerts a negative but statistically insignificant effect on the demand for hired labour.

The estimated effect of the village wage rate is positive and significant at 5 percent level, suggesting a forward bending demand curve for hired labour. The sign is inconsistent with the expectation that village wage rates exert a negative effect on the demand for hired labour. The result may be due to the fact that: (i) the demand for hired labour normally peaks at periods of labour requirements by all sections of the farm sector, and therefore the amount sup- 


\section{Mensah-Bonsu et al.}

plied would be offered at higher price by those who have excess labour; (ii) farmers have no substitute for human labour in undertaking oil palm farm activities such as slashing, pruning and harvesting. Therefore farmers are compelled to hire labour at higher offer price. Mensah-Bonsu (2003) has similarly estimated a forward bending hired labour demand curve for farmers in Northern Region of Ghana.

\section{SUMMARY}

The present study attempted to describe the structure of labour and estimate the factors which influence farmers' demand for hired labour for oil palm production in the Western Region of Ghana. Descriptive statistics and the ordinary least square regression techniques have been used for the estimations. The structure of labour reveals that farm activities in oil palm production are gender specific: hired labour for harvesting, slashing, pruning and ringweeding are provided mainly by males, while that for carrying of fresh fruit bunch is provided mainly by females. The structure of labour for oil palm farmers, from the present study, typifies a small-scale agricultural production, with few farmers using contract and salaried labour (14 percent and 11 percent, respectively) and fertilizer (30 percent) in production. The estimated regression results show that the value of investment in other inputs (e.g. fertilizer), village wage rate, size of oil palm farm and higher educational attainment by household members have positive and significant influences on oil palm farmers' demand for hired labour. The distance of the farm from home has a negative and significant influence. The estimated elasticity for each of these significant variables suggests that their individual effect on the demand for hired labour is inelastic.

\section{CONCLUSION}

The study concludes that labour continues to be a major cost component in maintaining matured oil palm farms in Ghana. It also notes that issues on labour requirement of oil palm farmers should be based on economic considerations such as the structure of labour of the farmers, farm size, village wage rate and cost of other productive inputs like fertilizer. Also, the accessibility of the farm is very important for encouraging farmers to use more hired labour. For oil palm production, carrying of fresh fruit bunches and slashing are two main activities that could be mechanized with much ease, under Governments' policy on agriculture contained in the Ghana Poverty Reduction Strategy which aims to reduce the drudgery of labourintensive farm work through modernized agriculture, but may lead to retrenchment of female and male hired labour, respectively. It is recommended that such agricultural policy when implemented should also seek ways for engaging any displayed hired labour in other employable opportunities or elsewhere. Development of more accessible routes (feeder and tarred roads), expansion of some ongoing nucleus outgrower schemes which increases farm size of farmers and programmes that encourage the use of productive input like fertilizer (investment in physical inputs) will help to generate more employment opportunities in the farm sector.

\section{REFERENCES}

Ahiaphor, R. (2003). The Impact of Ghana Oil Palm Development Company Project on the Beneficiary Farmers in the Kwae District, B.Sc. Dissertation, Department of Agricultural Economics and Agribusiness, University of Ghana, Legon, 40 pp.

Benjamin, C and Kimhi, A. (2006). Farm Work, Off-farm Work, and Hired Farm Labour: Estimating a Discrete-Choice Model of French Farm Couples' Labour Decisions, European Review of Agricultural Economics, 33 (2), pp. 149-171.

Cleave, J. H. (1974). African Farmers: Labor Use in the Development of Smallholder Agriculture. Praeger, New York, 253 pp.

Dvorak, K. (1996), Labor Requirement in Assessment of Technologies. IITA Research Guide No. 27, Training Program, $3^{\text {rd }}$ Edition, IITA, Ibadan, Nigeria, 14 pp. 
Enete, A. A., Nweke, F. I. and Tollens, E. (2005). Hired Labor Use Decisions in Cassava-Producing Households of SubSaharan Africa, Agricultural Economics, 33, pp. 269-275.

FAO (1986). Population and Labour Force in Rural Economies. Economic and Social Development Paper, 59, Rome, 169 pp.

Flinn, J. and Zuckerman, F. (1979). Resource Use, Income and Expenditure Patterns of Yoruba Smallholders, Agricultural Economics Discussion Paper No.9/79, IITA, Ibadan, Nigeria, pp. 825 - 835.

Ghana Poverty Reduction Strategy (2003). An Agenda for Growth and Prosperity: Analysis and Policy Statements, Republic of Ghana, Accra, 216 pp.

Ghana Statistical Service (1995). Analysis of Demographic Data in Ghana, Preliminary, Analysis Report. Vol.1, Accra, 243 pp.

Hill, B. and Ray, D. (1987). Economics for Agriculture: Food, Farming and the Rural Economy, Macmillan Education Ltd, Palgrave, $439 \mathrm{pp}$.

Johnson, D. T. (1982). The Business of Farming, A Guide to Farm Business Management in the Tropics. Macmillan Press Ltd., London, Basinstoke, 362 pp.

Kevane, M. (1994). Village Labour Markets in Sheikan District, Sudan, World Development, 22 (6), pp. $839-857$.

Leones, J. P. and Feldman, S. (1998). Nonfarm Activity and Rural Household Income: Evidence from Philippine Microdata, Economic Development and Cultural Change, 46 (4), pp. $789-806$.
Mensah-Bonsu, A. (2003). Migration and Environmental Pressure in Northern Ghana, $\mathrm{PhD}$. Dissertation, Vrije Universiteit Amstaderm, $206 \mathrm{pp}$.

Norman, D. W. (1973). Labour Inputs of Farms: A case Study of Zaire Province of North Central State of Nigeria. Samaru Research Bulletin 116. Institute for Agricultural Research, Samaru, Nigeria, 48 pp.

Okyere, A. (1985). The State of the Vegetable oil Industry in Ghana before the 1980s. An Economic Survey. Technical Publication Series. No. 52, ISSER, University of Ghana, Legon, $81 \mathrm{pp}$.

Olayide, S. O., Atobatele, J. I. (1980). Farm Labor Use and Nigerian Small Farmers. In: Olayide, S. O., Eweka, J. A., Bello-Osagie, V. E. (Eds.), Nigerian Small Farmers: Problems and Prospects in Integrated Rural Development, Published by CARD, University of Ibadan, Nigeria, pp. 149159.

Otoo, W. (1993). Economics of Oil palm Production in Twifo Praso District of Central Region, M. Phil. Thesis, Department of Agricultural economics and Agribusiness, University of Ghana, Legon, 38 pp.

Rourke, B. E. (1974), Wages and Incomes of Agriculture Workers in Ghana, A Report to the International Labour Organization, Geneva, 137 pp.

Vlek, P. L. G. (1990). The Role of Fertilizers in Sustaining Agriculture in Sub-Saharan Africa, Fertilizer Research, 26, pp. 327339. 